the knee joint of 11 patients with RA were on average 3.7-fold higher $(p<0.001)$ than in those of 11 subjects with knee osteoarthritis and correlated with paired serum values $(r=0.65$, $p=0.039)$. This suggests that circulating IIINys levels reflect in part local joint synovial tissue contribution.

Using a specific antibody, we showed that the IIINys sequence of type III collagen is highly nitrated in the synovium of patients with RA, in support of the growing body of evidence underscoring a central role for free radicals and $\mathrm{NO}$ in chronic inflammation. ${ }^{9}{ }^{10}$ Markedly elevated serum IIINys values were detected in patients with active RA, suggesting that this biochemical marker may be useful for the clinical investigation of oxidative-mediated joint damage and for assessing effects of NO-targeted therapies. Further studies are required to determine whether serum IIINys reflects specifically synovial tissue inflammation and/or more general NO-mediated processes.

\section{N Charni-Ben Tabassi, ${ }^{1}$ P Richardot, ${ }^{1}$ L Toh, ${ }^{2}$ H Marotte, ${ }^{2}$ A-C Bay-Jensen, ${ }^{3}$ P Miossec, ${ }^{2}$ P Garnero ${ }^{1,4}$}

${ }^{1}$ Molecular Markers, SYNARC, Lyon, France; ${ }^{2}$ Unité Mixte HCL bioMerieux, E. Herriot Hospital, Lyon, France; ${ }^{3}$ Department of Clinical Cell Biology, IRS/CSFU, University of Southern Denmark, Vejle Hospital, Vejle, Denmark; ${ }^{4}$ INSERM Research Unit 664, Lyon, France

Correspondence to: Dr P Garnero, Synarc, 16 rue Montbrillant, 69003 Lyon, France; patrick.garnero@synarc.com
Competing interests: None declared.

Accepted 20 July 2008

Ann Rheum Dis 2009;68:451-452. doi:10.1136/ard.2008.097915

\section{REFERENCES}

1. Sweeeny SE, Firestein GS. Rheumatoid arthritis: regulation of synovial inflammation. Int J Biochem Cell Biol 2004;36:372-8.

2. Jang D, Murrell GA. Nitric oxide in arthritis. Free Radic Biol Med 1998;24:1511-9.

3. Stefanovic-Racic M, Stadler J, Georgescu HI, Evans CH. Nitric oxide synthesis and its regulation by rabbit synoviocytes. J Rheumatol 1994;21:1892-8.

4. Beckman JS, Koppenol WH. Nitric oxide, superoxide, and peroxynitrite: the good, the bad, and ugly. Am J Physiol 1996;271:1424-37.

5. Mapp PI, Klocke R, Walsh DA, Chana JK, Stevens CR, Gallagher PJ, et al. Localization of 3-nitrotyrosine to rheumatoid and normal synovium. Arthritis Rheum 2001;44:1534-9.

6. Sandhu JK, Robertson S, Birnboim HC, Goldstein R. Distribution of protein nitrotyrosine in synovial tissues of patients with rheumatoid arthritis and osteoarthritis. J Rheumatol 2003;30:1173-81.

7. Garnero P, Rousseau JC, Delmas PD. Molecular basis and clinical use of biochemical markers of bone, cartilage, and synovium in joint diseases. Arthritis Rheum 2000:43:953-68.

8. Garnero P, Piperno M, Gineyts E, Christgau S, Delmas P, Vignon E. Cross-sectional evaluation of biochemical markers of bone, cartilage and synovial tissue metabolism in patients with knee osteoarthritis: Relations with disease activity and joint damage. Ann Rheum Dis 2001;60:619-26

9. Abramson SB, Yazici Y. Biologics in development for rheumatoid arthritis: relevance to osteoarthritis. Adv Drug Deliv Rev 2006 20;58:212-25.

10. Scher JU, Pillinger MH, Abramson SB. Nitric oxide synthases and osteoarthritis. Curr Rheumatol Rep 2007:9:9-15.

\title{
Correction
}

There was an omission in an article published in the December 2008 Supplement (Furst DE, Keystone EC, Kirkham B, Fleischmann R, Mease P, Breedveld FC, et al. Updated consensus statement on biological agents for the treatment of rheumatic diseases, 2008. Ann Rheum Dis 2008;67(Supp13):iii2-iii25). A Kavanaugh should have been added to the consensus statement as the fourth author. The statement should have read as follows: "AK conducts clinical research studies sponsored by Abbott, Amgen, BMS, Genentech, Biogen-Idec, UCB and Centocor."

doi:10.1136/ard.2008.100834.corr1 